African Crop Science Journal by African Crop Science Society is licensed under a Creative Commons Attribution 3.0 Uganda License. Based on a work at www.ajol.info/ and www.bioline.org.br/cs DOI: https://dx.doi.org/10.4314/acsj.v28i2.6

\title{
STORAGE ROT OF SEED YAM RESULTING FROM SPEARGRASS INJURIES
}

\author{
A.K. AIDOO ${ }^{1,2}$, S. ARTHUR ${ }^{1,2}$, G. BOLFREY-ARKU ${ }^{1}$, K. OSEI $^{1}$, J.N.L. LAMPTEY', \\ M.B. MOCHIAH ${ }^{1}$, G. OHENE-MENSAH ${ }^{1}$, F. FRIMPONG ${ }^{1,3}, \mathrm{Z}^{2}$. APPIAH-KUBI ${ }^{1,2}$ \\ and E. OWUSU DANQUAH ${ }^{1,4}$ \\ ${ }^{1}$ CSIR-Crops Research Institute, P. O. Box 3785, Kumasi, Ghana \\ ${ }^{2}$ Department of Crop and Soil Science, Faculty of Agriculture, CANR, KNUST, Kumasi, Ghana \\ ${ }^{3}$ Forschungszentrum Jülich, Institute of Bio-Geosciences 2, Plant Sciences, Germany \\ ${ }^{4}$ Department of Plant, Soil and Microbial Sciences, Michigan State University, USA \\ Corresponding author: inceaidoo07@yahoo.co.uk
}

(Received 15 July 2019; accepted 26 June 2020)

\begin{abstract}
Postharvest rot due to injury is a major contributing factor to the declining quality of stored seed yams (Dioscorea spp.). Among the several known injuries, the piercing effect of speargrass rhizomes has become a serious constraint for yam production in Ghana. The objective of this study was to assess injuries on seed yams resulting from piercing of speargrass rhizomes and their effects on postharvest rots in Ghana. Eighty farmer fields from Mem, Watro, Asanteboa and Abour in the Atebubu-Amantin Municipal in the Bono East Region of Ghana were screened for speargrass incidence and injury on harvested tubers, for laboratory analysis of pathogens in 2016 and 2017. The tubers were sorted into four categories of seed yam based on weight. Thirty seed yams each of two selected white yam cultivars (Dente and Kpamyo) with visible speargrass rhizome-pierced-tubers (VSRPT) and nonspeargrass rhizome pierced healthy tubers (NSRPHT) were randomly selected and stored in a ban for weekly assessment of rot. The rotten tissues from the localised area of VPSRT were subjected to pathological investigations in the laboratory. The incidence of injury seemingly increased with increasing tuber weight. It was $0 \%$ for $<100 \mathrm{~g}$ samples and averagely $14 \%$ for $>1 \mathrm{~kg}$ samples, irrespective of cultivars and locations. Incidence of rot from NSRPHT sample was observed 5 weeks after storage (WAS) for both cultivars; and 2 WAS from the VSRPT sample and 40\% higher than NSRPHT at 8 WAS. Eight and six known rot pathogens were isolated from the rotten tissues of VSRPT of Dente and Kpamyo, respectively. Injury from the piercing of speargrass rhizome significantly contributed to hastening of tuber rots; while tuber injury increased with increasing speargrass density. Appropriate management of speargrass is essential for commercial seed yam growers to reduce tuber damage which affects yam quality, storage and marketing.
\end{abstract}

Key Words: Dioscorea, postharvest, rot pathogen, speargrass rhizome 
La pourriture post-récolte due à une déchirure est un facteur majeur contribuant à la baisse de la qualité des ignames des semences stockées (Dioscorea spp.). Parmi les nombreuses déchirures connues, l'effet perçant des rhizomes de la gerbe d'herbe est devenu une contrainte sérieuse pour la production d'igname au Ghana. L'objectif de cette étude était d'évaluer les déchirures sur les ignames de semence résultant du perçage des rhizomes de gerbe d'herbe et leurs effets sur les pourritures postrécolte au Ghana. Quatre-vingts champs d'agriculteurs de Mem, Watro, Asanteboa et Abour dans la

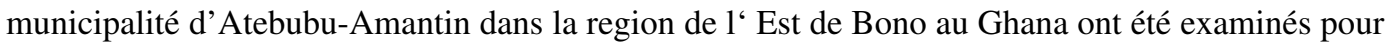
déterminer l'incidence et les dommages de la gerbe d'herbe sur les tubercules récoltés, pour une analyse en laboratoire des agents pathogènes en 2016 et 2017. Les tubercules ont été triés en quatre catégories d'igname de semence en fonction du poids. Trente ignames de semence de chacun des deux cultivars sélectionnés d'igname blanche (Dente et Kpamyo) avec des tubercules percés de rhizome de gerbe d'herbe (VSRPT) et des tubercules sains percés de rhizome non- gerbe d'herbe (NSRPHT) ont été sélectionnés au hasard et stockés dans une interdiction pour une évaluation hebdomadaire de la pourriture . Les tissus pourris de la zone localisée de VPSRT ont été soumis à des investigations pathologiques en laboratoire. L'incidence des déchirures a apparemment augmenté avec l'augmentation du poids des tubercules. Il était de $0 \%$ pour les échantillons $<100 \mathrm{~g}$ et de $14 \%$ en moyenne pour les échantillons $>1 \mathrm{~kg}$, quels que soient les cultivars et les emplacements. L'incidence de pourriture de l'échantillon NSRPHT a été observée 5 semaines après stockage (WAS) pour les deux cultivars; et 2 WAS de l'échantillon VSRPT et $40 \%$ plus élevés que NSRPHT à 8 WAS. Huit et six agents pathogènes de la pourriture connus ont été isolés respectivement dans les tissus pourris du VSRPT de Dente et de Kpamyo. Les déchirures causées par le perçage du rhizome de gerbe d'herbe ont considérablement contribué à accélérer la pourriture des tubercules; tandis que les dommages aux tubercules augmentaient avec l'augmentation de la densité de la gerbe d'herbe. Une gestion appropriée de la groseille verte est essentielle pour les producteurs commerciaux d'ignames de semence afin de réduire les dommages aux tubercules qui affectent la qualité, le stockage et la commercialisation des ignames.

Mots Clés: Dioscorea, post-récolte, pathogène de la pourriture, rhizome de la gerbe d'herbe

\section{INTRODUCTION}

Yam (Dioscorea spp.) is a prominent staple crop for food security and income generation in the tropical regions of Africa. Various yam cultivars are produced, but white yam (Dioscorea rotundata) is the most important and popular species grown in the tropics (Aighewi et al., 2015). According to Anaadumba (2013), yam accounts for 16 percent of Ghana's agricultural contribution to gross domestic product (GDP). The country is currently the leading exporter of yam in Sub-Saharan Africa contributing 36\% of the world's total (Asante et al., 2013).

Despite the importance of this crop to Ghana, its production faces several challenges, all of which threaten rural livelihood and urban food security. A major reason for poor yield is the limited availability of quality planting materials, devoid of pest, diseases and damage caused by weed infestation, especially the rhizomes of speargrass (Imperata cylindrica Linn.). Quality seed yam supply chain, generally is scarce due to low multiplication rates and, therefore, very expensive (Aidoo $e t$ al., 2011).

Speargrass is listed as one of the top ten most troublesome weeds in the world because of its invasiveness and difficulty to control (Koger and Bryson, 2004; MacDonald, 2004). It has colonised many areas in Latin America, tropical Asia, and some parts of West Africa due to its ability to propagate through both 
sexual and asexual means, among other adaptive characteristics (Chikoye et al., 2000; King and Grace, 2000; Sellers et al., 2015). It is known to cause a lot of injuries to roots and tubers in Sub-Saharan African countries, which affects crop quality (Bolfrey-Arku et al., 2006).

Postharvest rot is a major factor limiting the shelf life of yam, and losses could be high, which subsequently affect the income of traders and farmers, availability of planting materials and food security (Aidoo, 2015a). The objective of this study was to assess injuries on seed yams resulting from the piercing mechanism of speargrass rhizomes and their effects on postharved rots, as well as determining the associated rot causal agents.

\section{MATERIALS AND METHODS}

Study area. The study was conducted in the Atebubu-Amantin Municipal Assembly of Ghana (lat. $7.7500^{\circ}$ long. $-0.983300^{\circ}$ ) in 2016 and 2017 planting seasons. Data were collected from forty farms in each year. Four communities were selected for this study based on their high level of involvement in seed yam production during the period of study. The communities were inhabitants of Mem (lat. $7.651122^{\circ}$ long. $-0.952794^{\circ}$ ), Watro (lat. 7.597775 long. $-0.955133^{\circ}$ ), Abour (lat. 7.628164 long. $-1.132014^{\circ}$ ) and Asanteboa (lat. $7.652683^{\circ}$ long. $-1.104072^{\circ}$ ). All fields were planted with white yam cultivars, namely, Dente, Serwa, Leelee, Pona, Yesu Mogya, Maama Koma and Kpamyo. The average cultivated area for all screened seed yam farms was $404.7 \mathrm{~m}^{2}$. The fields were manually cleared and ridged at $1 \mathrm{~m}$ spacing, using cutlasses and hoes.

Planting materials and field establishment. The source of planting materials was mostly from previous season's harvest and open market. Planting materials were cut into minisetts size of $30-50 \mathrm{~g}$ and treated with Lambda cyhalothrin insecticide and Ethylene bisdithiocarbamate fungicide.
Treated minisetts were air-dried under shade, before planting at within row spacing of $30-50 \mathrm{~cm}$. Minisetts were planted between May and June, while seed yams were harvested in December and January for each year. Management of weeds was done manually, with cutlasses and hoes, 3 to 5 times before harvesting of crop.

Weed assessment. Speargrass plants were counted within a quadrat $\left(0.25 \mathrm{~m}^{2}\right)$ placed randomly, three times within the middle rows in a $30 \mathrm{~m}^{2}$ designated plot to measure density (plant $\mathrm{m}^{-2}$ ) at 4 and 6 months after planting (MAP). The above ground part of speargrass within the quadrat area was harvested at ground level, with a sharp knife, air dried for 3 - 4 days and oven dried to obtain dry weight.

Speargrass injury on tubers. On the designated $30 \mathrm{~m}^{2}$ plot area within each farm, seed yams were harvested and sorted into four different categories, based on weight as: ware yam (> $1000 \mathrm{~g})$, seed yam A (500 - $999 \mathrm{~g})$, seed yam B (100- $499 \mathrm{~g})$ and micro-tubers (< 100 g), (CAY-Seed Report, 2018). Damage caused by speargrass was assessed by expressing the yield weights of injured seed yams as a percentage of the total weight of seed yams harvested for a particular category.

Storage rot assessment. An in vitro study was conducted in the second year at CSIR Crops Research Institute, Fumesua - Kumasi. Thirty seed yams each of two selected white yam cultivars (Dente and Kpamyo) from the VSRPT and NSRPHT samples, were randomly selected and stored in a ban at the CSIR-CRI for weekly assessment of rot for eight weeks. The NSRPHT samples served as controls. Rotten tubers were sampled and the rotten tissues from the localised area of VSRPT were subjected to pathological investigations in the laboratory. Pieces of tissues $\left(1 \mathrm{~cm}^{-3}\right)$ were cut from the periphery of the rotten portions with a sterile knife, and surface-sterilised in 5\% sodium hypochlorite solution for 2-3 minutes; and washed three times with distilled water. 
The tissues were allowed to dry in a sterile laminar flow chamber (BASSAIRE, Southampton, UK) for $1 \mathrm{hr}$. For each sample, 20 pieces of rotten tissues were seeded in Petri dishes containing solidified potato dextrose agar (PDA) medium (Oxoid Ltd, Hants, UK); and incubated at a temperature of $27 \pm 2{ }^{\circ} \mathrm{C}$ by placing them in an incubator (GALLENKAMP, SN. 8095/10/295, UK). Mycelia that grew 2 days from the plated yam tissues were subcultured onto fresh PDA. Subsequent subculturing was done until pure cultures of isolates were obtained. These isolates were identified using morphological characteristics, following the standards of Mathur and Kongsdal (2003) and Barnett and Hunter (1972).

For bacteria, the rotten tissues were plated on a nutrient agar medium (Oxoid Ltd, Hants, UK). The frequency of occurrence was calculated for each yam cultivar by determining the number of times a pathogen was isolated from the rotten tubers expressed as a percentage of the total number of pathogen specific colonies observed.

Statistical analysis. Data on speargrass density, biomass, rhizome-pierced injury and damage on tubers were subjected to analysis of variance, following the procedure of GenStat 12.0. The raw count data were square root transformed (i.e. $\checkmark(1+0.5)$ ) before the analysis. Significant treatment means were separated using standard error of deviation (SED). The Pearson correlation was performed on speargrass density, biomass, damage and injury on seed yam.

\section{RESULTS AND DISCUSSION}

Speargrass density, injury and damage Seventy three percent of fields visited were infested with speargrass. A significantly high speargrass density of $172-223$ plants $\mathrm{m}^{-2}$ were recorded at Watro and Mem fields, relative to $<42$ plant $\mathrm{m}^{-2}$ at Abour and Asanteboa (Table 1) during the developmental phase of the crop. This indicates a probable initial dominance of speargrass in the former two communities. Bolfrey-Arku (2006) reported 51\% farmers in the same ecological zone, noting inadequate control of speargrass manually. The type of manual implement used in the control of persistent weed as speargrass, has relevance on its density and growth. MacDonald (2004) confirms that commonly used weed control practices like manual slashing encourages the spread and growth of rhizomes. It may also be that, besides the inappropriate choice of control method, the control of speargrass and other weeds may not have been on time.

Generally, $26 \%$ of the harvested tubers were visibly pierced by speargrass rhizomes across categories, with the highest incidence

TABLE 1. Speargrass density and above ground biomass for Atebubu-Amantin Municipality, Ghana

\begin{tabular}{lccccc}
\hline Community & \multicolumn{2}{l}{ Speargrass density $\left({\left.\mathrm{plant} \mathrm{m}^{-2}\right)}\right.$} & & \multicolumn{2}{l}{ Speargrass biomass $\left(\mathrm{g} \mathrm{m}^{-2}\right)$} \\
\cline { 2 - 3 } \cline { 6 - 6 } & $4 \mathrm{MAP}$ & $6 \mathrm{MAP}$ & & $4 \mathrm{MAP}$ & $6 \mathrm{MAP}$ \\
\hline Abour & 35.33 & 39.50 & & 11.00 & 14.00 \\
Asanteboa & 39.84 & 42.17 & & 15.34 & 13.33 \\
Mem & 186.35 & 172.17 & & 87.33 & 83.33 \\
Watro & 223.34 & 223.86 & & 96.67 & 125.15 \\
SED & 23.97 & 15.38 & & 10.15 & 23.45 \\
\hline
\end{tabular}

MAP $=$ Months after planting 
of $45 \%$ from the Watro fields, followed by Mem (Table 2). These two communities are in close proximity; therefore, they may have similar management practices which inadequately disrupts the piercing activities of the growing rhizomes and emerging shoots on the tubers.

Significant differences in incidence of injury existed among the seed yam categories (Table 2). Ware yam consistently recorded the highest incidence, among communities with an average of $14.1 \%$, followed by seed yam A; while the micro-tubers had no visible speargrass rhizome pierced injury. This could be due to the surface area of exposure; bigger tubers provided relatively more surface area for speargrass rhizome interaction and injury. It can be inferred that tubers that stay longer in the soil may not escape speargrass rhizome injury; thus for quality tubers which attract premium price, they should not be stored for long on speargrass infested fields. In Ghana, speargrass causes significant reduction in the quality and market value of root and tuber crops especially yam, cassava, cocoyam and sweet potato (Aflakpui and Bolfrey-Arku, 2007).

A critical analysis of the probability $(\mathrm{P})$ and coefficient of correlation $\left(\mathrm{r}^{2}\right)$ values indicate a strong relationship between speargrass infestation and rhizome injury on all categories of tubers up to 6 MAP, except seed yam B. Table 3 indicates that $51 \%$ of damage to tubers is related to speargrass infestation. Rhizomes make more than $60 \%$ of the entire plant biomass, with about 72 or $50 \%$ occurring in 15 or $20 \mathrm{~cm}$ soil depth, respectively (Brook, 1989; MacDonald, 2004; Daneshgar et al., 2008). Apart from seed yam $B$, the $r^{2}$ of 60 $80 \%$ seemed to confirm that the bigger the surface area of exposure, the higher the incidence of speargrass rhizome injury on tubers; thereby increasing the risk of postharvest tuber rot. However, the duration of speargrass infestation on the field also strongly correlated with rhizome injury, and confirmed by the non-significant correlation (Table 3) of speargrass density at 6 MAP and seed B (small seed size).

Rot assessment. The rate of rot was faster in the visible speargrass rhizome-pierced tubers (VSRPT) than the non speargrass rhizome-pierced healthy tubers (NSRPHT) (Fig. 1). The incidence of rot from the VSRPT sample was observed 2 weeks after storage (WAS) for both cultivars, and 5 WAS from the NSRPHT sample. By 8 WAS, the incidence of rot from the VSRPT was $40 \%$ higher over the NSRPHT. The rot incidence at the end of storage for Dente and Kpamyo was 67 and $60 \%$, respectively for VSRPT. Comparatively, Dente recorded $27 \%$ rot while Kpamyo had $13 \%$ for the NSRPHT. This confirms other studies that speargrass injury on tubers create entry points for rot pathogens (Chikoye et al.,

TABLE 2. Incidence of speargrass injury on harvested seed yams for Atebubu-Amantin Municipal, Ghana

\begin{tabular}{lccccc}
\hline Yam category & \multicolumn{3}{c}{ Incidence of speargrass injury on tubers (\%) } & Average \\
\cline { 2 - 5 } & Abour & Asanteboa & Mem & Watro & \\
\hline Ware & 5.14 & 5.94 & 17.90 & 27.59 & 14.14 \\
Seed A & 3.23 & 2.82 & 12.92 & 11.10 & 7.52 \\
Seed B & 1.34 & 2.44 & 6.17 & 5.89 & 3.96 \\
Micro & 0.00 & 0.00 & 0.00 & 0.00 & 0.0 \\
SED $=1.31$ & & & & & \\
\hline
\end{tabular}


TABLE 3. Pearson correlations for speargrass density, speargrass biomass, seed A, B and Ware injury incidence and \% damage pooled over experiments

\begin{tabular}{lcc}
\hline Parameter & P value & $\mathrm{R}^{2}$ \\
\hline Speargrass density @ 4MAP vrs Seed B injury incidence & 0.038 & 0.507 \\
Speargrass density @ 4MAP vrs Seed A injury incidence & 0.006 & 0.638 \\
Speargrass density @ 4MAP vrs Ware injury incidence & 0.0001 & 0.817 \\
Speargrass density @ 4MAP vrs \% Damage & 0.037 & 0.509 \\
Speargrass density @ 6MAP vrs Seed B injury incidence & 0.125 & 0.38 \\
Speargrass density @ 6MAP vrs Seed A injury incidence & 0.02 & 0.539 \\
Speargrass density @ 6MAP vrs Ware injury incidence & 0.0002 & 0.781 \\
Speargrass density @ 6MAP vrs \% Damage & 0.0381 & 0.506 \\
Speargrass biomass @ 4MAP vrs seed B injury incidence & 0.095 & 0.418 \\
Speargrass biomass @ 4MAP vrs seed A injury incidence & 0.0053 & 0.644 \\
Speargrass biomass @ 4MAP vrs Ware injury incidence & $<0.0001$ & 0.832 \\
Speargrass biomass @ 4MAP vrs \% Damage & 0.0159 & 0.576 \\
Speargrass biomass @ 6MAP vrs seed B injury incidence & 0.124 & 0.388 \\
Speargrass biomass @ 6MAP vrs seed A injury incidence & 0.0166 & 0.571 \\
Speargrass biomass @ 6MAP vrs Ware injury incidence & $<0.0001$ & 0.833 \\
Speargrass biomass @ 6MAP vrs \% Damage & 0.0194 & 0.560 \\
\hline
\end{tabular}

*Data were pooled over 2 years with 4 communities and 2 varieties at $\mathrm{P}=0.05$

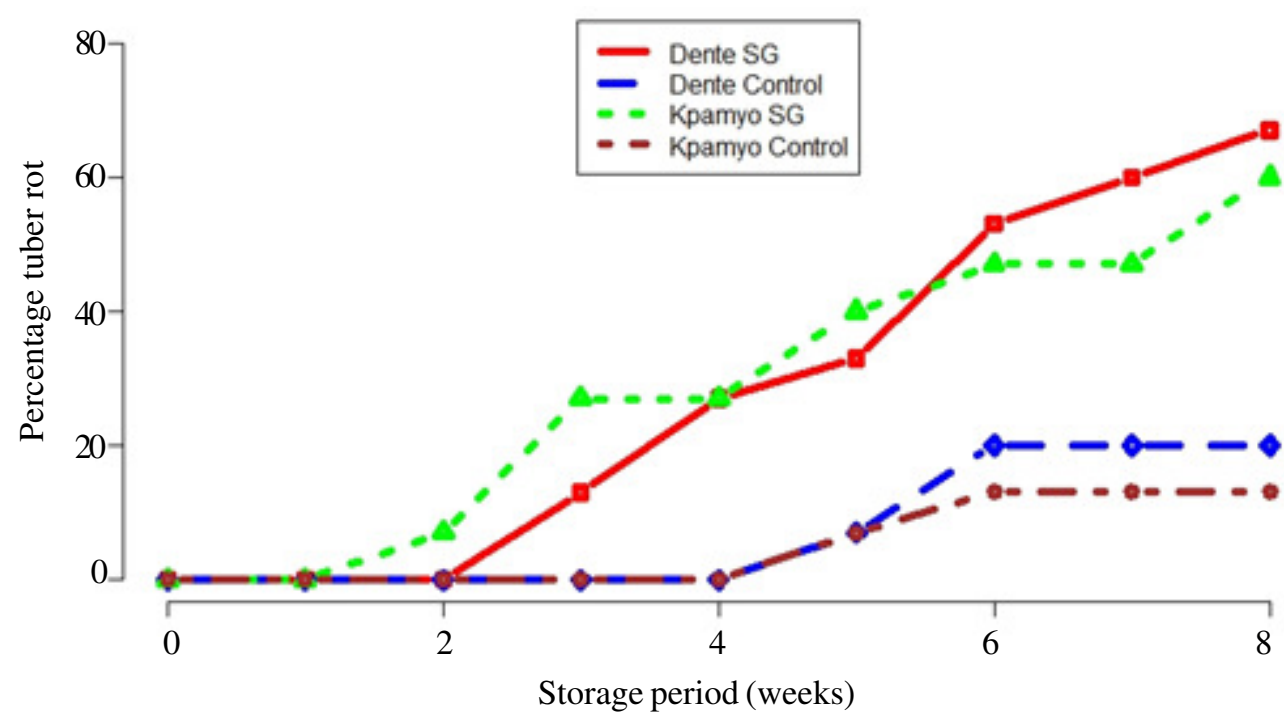

Figure 1. Effect of speargrass injuries on postharvest rot of Dente and Kpamyo seed yams. 
TABLE 4. Morphological characteristics of identified fungi associated with rotten yam tubers from storage

\begin{tabular}{|c|c|c|c|c|c|c|c|}
\hline Identified Fungus & $\begin{array}{l}\text { Colony } \\
\text { texture }\end{array}$ & $\begin{array}{l}\text { Colony } \\
\text { diameter } \\
(\mathrm{cm})\end{array}$ & Upper view & $\begin{array}{l}\text { Reverse } \\
\text { view }\end{array}$ & Nature of hyphae & $\begin{array}{l}\text { Nature of } \\
\text { conidiophore }\end{array}$ & Conidia \\
\hline Alternaria alternata & & $5.5-7$ & Dark brown & Blackish & $\begin{array}{l}\text { Branched hyphae, } \\
\text { septated }\end{array}$ & Simple and straight & $\begin{array}{l}\text { Ovoid, formed } \\
\text { in long chains }\end{array}$ \\
\hline Lasiodiplodia theobromae & Cottony & 7- 8 & Blackish & Greyish & $\begin{array}{l}\text { Thin, uniform and } \\
\text { thread-like }\end{array}$ & Not clearly visible & $\begin{array}{l}\text { Hyaline, double } \\
\text { layered and } \\
\text { unicellular }\end{array}$ \\
\hline Aspergillus niger & Powdery & $5-6$ & Dark brown & Off-white & Presence of phialides & Brown and broad & $\begin{array}{l}\text { Globose to } \\
\text { irregularly rough }\end{array}$ \\
\hline Aspergillus flavus & Powdery & $6-7$ & Yellowish green & Pale yellow & Conidial head radiate & $\begin{array}{l}\text { Long, hyaline and } \\
\text { walled }\end{array}$ & $\begin{array}{l}\text { Subglobose or } \\
\text { globose }\end{array}$ \\
\hline Rhizopus stolonifer & Fluffy & Covered plate & Greyish & Brownish & Columella oval & $\begin{array}{l}\text { Subglobose and } \\
\text { rigid sporangiophore }\end{array}$ & $\begin{array}{l}\text { Sporangia thick } \\
\text { walled, pale to } \\
\text { brown }\end{array}$ \\
\hline Fusarium oxysporum & Floccose & $5-6$ & Whitish & Purple & $\begin{array}{l}\text { Presence of } \\
\text { macroconidia }\end{array}$ & & \\
\hline Penicillium italicum & & $4-6$ & Blue & Pale yellow & Septated and hyaline & Smooth & $\begin{array}{l}\text { Ellipsoidal to } \\
\text { cylindrical }\end{array}$ \\
\hline
\end{tabular}


TABLE 5. Frequency of occurrence for identified rot pathogens from rotten yam tubers for two yam cultivars

\begin{tabular}{lcc}
\hline Identified fungi & \multicolumn{2}{c}{ Frequency of occurrence (\%) } \\
\cline { 2 - 3 } & Dente & Kpamyo \\
\hline A. alternata & 4.2 & 0 \\
L. theobromae & 35.3 & 30.9 \\
A. niger & 20.8 & 19.1 \\
A. flavus & 18.8 & 14.3 \\
R. stolonifer & 6.3 & 11.9 \\
F. oxysporum & 10.4 & 14.3 \\
P. italicum & 4.2 & 9.5 \\
A bacterium & 2.6 & 0 \\
\hline
\end{tabular}

2000; Aflakpui and Bolfrey-Arku, 2007). The results point to the fact that tubers with speargrass rhizome injuries rot faster than healthy-looking tubers with no speargrass rhizome injury.

Isolation and identification of rot pathogens. A total of 90 fungal colonies were recorded on 40 plated tissues of rotten tubers. Seven fungal species from six genera, were identified to be associated with storage rots. These were Alternaria alternata, Lasiodiplodia theobromae, Aspergillus niger, A. flavus, Rhizopus stolonifer, Fusarium oxysporum and Penicillium italicum (Table 4). A bacterium, Erwinia sp. was also identified as a rot pathogen. Lasiodiplodia theobromae with the highest frequency of occurrence of 35.3 and $30.9 \%$ was recorded on Dente and Kpamyo, respectively (Table 5). These pathogens have been identified as being associated with postharvest yam tuber rot disease in Ghana (Aboagye-Nuamah et al., 2005; Aidoo, 2015b).

The present study has established the perceived association between speargrass rhizome injury and storage rot by actors in the yam value chain. Storage rot organisms currently constitute a major threat to the massive potential of yam in improving food security and safety, hence the integrated management of speargrass on the field should be an integral part of postharvest storage practices of seed yam.

\section{ACKNOWLEDGEMENT}

We acknowledge the financial support from the CAY-Seed project, which was implemented by CSIR-Crops Research Institute, Ghana. Contributions from Messrs Augustine Agyekum, Micah Offei Apraku and the staff of the Plant Health Division of CSIR-CRI, Ghana, are acknowledged.

\section{REFERENCES}

Aboagye-Nuamah, F., Offei, S.K., Cornelius, E.W. and Bancroft, R.D. 2005. Severity of spoilage storage rots of white yam (Dioscorea rotundata Poir.) Annals of Applied Biology 147(2):183-190.

Aflakpui, G.K.S. and Bolfrey-Arku, G.E.-K. 2007. Integrated management of Imperata cylindrica (speargrass) in yam and cassava: Weed pressure in crop, crop growth and yield. USA. Journal of Plant Science 2(1):14-24.

Aidoo, A.K. 2015a. Improving pit storage systems to reduce rots of whiteyam (Dioscorea rotundata) in Ghana. Scientific Journal of Agricultural Research \& Management 9: 4. Article ID sjarm-288, 4 Pages doi:10.7237/sjarm/288.

Aidoo, A.K. 2015b. Bioactivity of Zingeber officinale and Piper nigrum plant extracts in controlling post-harvest white yam (Dioscorea rotundata) tuber rot fungi. African Journal of Microbiology Research 9(22):1499-1503.

Aidoo, R., Nimoh, F., Bakang, J.E.A., OheneYankyera, K., Fialor, S.C. and Abaidoo, R.C. 2011. Economics of small-scale seed yam production in Ghana: Implications for commercialisation. Journal of Sustainable Development in Africa 13(7):65-78. 
Aighewi, B.A., Asiedu, R., Maroya, N. and Balogun, M. 2015. Improved propagation methods to raise the productivity of yam (Dioscorea rotundata Poir.). Food Security 7(4):823-834.

Anaadumba, P. 2013. Analysis of incentives and disincentives for yam in Ghana. Technical notes series, MAFAP, FAO, Rome, Italy.

Asante, B.O., Villano, R.A. and Battese, G.E. 2013. The effect of the adoption of yam minisett technology on the technical efficiency of yam farmers in the ForestSavanna transition of Ghana. African Journal of Agricultural and Resource Economics 9(2):75-90.

Barnett, H.L. and Hunter, B.B. 1972. Illustrated Genera of Imperfect Fungi. 3rd Edition. Burg. Pub. Co.

Bolfrey-Arku, G.E-K., Onokpise, O.U., Carson, A.G., Shilling, D.G. and Coultas, C.C. 2006. The speargrass (Imperata cylindrica (L.) Beauv.) menance in Ghana: Incidence, farmer perceptions and control practices in the forest and forest-savanna transition agro-ecological zones of Ghana. West African Journal of Applied Ecology 10:177-188.

Brook, R.M. 1989. Review of literature on Imperata cylindrica (L.) Raeuschel with particular reference to South East Asia. Tropical Pest Management 35(1):1225.https://doi.org/10. 1080/096708789 09371312

CAY-Seed Report. 2018. CAY-Seed project annual report submitted to the Donor, Bill and Melinda Gates Foundation.

Chikoye, D., Manyong, V.M. and Ekeleme, F. 2000. Characteristics of speargras
(Imperata cylindrica) dominated fields in West Africa: Crops, soil properties, farmer perceptions and management strategies. Crop Protection 19:481-487.

Daneshgar, P., Jose, S., Collins, A. and Ramsey, C. 2008. Cogongrass (Imperata cylindrica), an alien invasive grass, reduces survival and productivity of an establishing pine forest. Forest Science 54(6):579-587.

King, S.E. and Grace, J.B. 2000. The effects of gap size and disturbance type on invasion of wet pine savanna by speargrass, Imperata cylindrica (Poaceae). American Journal of Botany 87(9):1279-1286. https:/ /doi.org/10.2307/2656721.

Koger, C.H. and Bryson, C.T. 2004. Effect of speargrass (Imperata cylindrica) extracts on germination and seedling growth of selected grass and broadleaf species. Weed Technology 18(2): 236-242. https://doi.org/10.1614/wt-03-022r1.

MacDonald, G.E. 2004. Speargrass (Imperata cylindrica) - Biology, ecology, and management. Critical Reviews in Plant Sciences 23(5):367-380. https://doi.org/ 10.1080/07352680490505114

Marthur, S.B. and Kongsdal, O. 2003. Common laboratory seed health testing methods for detecting fungi, 2nd Edition. Int. Seed Testing Association. Switzerland. Sellers, B.A., Ferrell, J.A., Macdonald, G.E., Langeland, K.A. and Flory, S.L. 2015. Speargrass (Imperata cylindrica) biology, ecology, and management in Florida Grazing Lands 1. Series of the Agronomy Department, University of Florida, Institute of Food and Agricultural Sciences Extension 52:1-5. 